\title{
Az 1968. évi csehszlovákiai bevonulás magyar kontingensének térképellátása
}

(Provision of Maps in the Hungarian Contingent in the 1968 Invasion of Czechoslovakia)

\section{Absztrakt}

A Varsói Szerződés csapatai 1968 nyarán — hadgyakorlatnak álcázott felvonulás eredményeképpen — megszállták a Csehszlovák Szocialista Köztársaságot. Ebben az intervencióban a Magyar Népköztársaság Magyar Néphadseregének a kijelölt alakulatai is részt vettek. Feladatuk a Felvidék déli sávjának a megszállása volt. A tervezett cselekmények végrehajtása érdekében a Magyar Néphadsereg érintett csapatait az érintett területek különböző méretarányú térképeivel ellátták ugyan, ez az ellátmány azonban meglehetősen hiányos volt. A térképellátás nehézségei ellenére a magyar csapatok — a katonák önzetlen és magas szintű szolgálatellátásából fakadóan — a feladataikat eredményesen és minimális veszteségek árán valósították meg. Az 1968. évi megszállás tapasztalatai figyelembe vételével alakították újjá a Magyar Néphadsereg térképészeti szolgálatát.

\section{Kulcsszavak}

Magyar Néphadsereg térképészeti szolgálata ；1968. évi csehszlovákiai bevonulás ; Magyar Néphadsereg „Zala” hadgyakorlata ; a „Zala” hadgyakorlat térképészeti biztosítása ; a Felvidék katonaföldrajza

\section{Abstract}

In summer 1968, the troops of the Warsaw Pact - disguised as a war gaming exercise - invaded the Czechoslovak Socialist Republic. Certain units of the Hungarian People's Army participated in this intervention; their responsibility was to occupy the southern area of Slovakia. In order to successfully accomplish the mission, the concerned units of the Hungarian People's Army were provided various topographical maps of the area, the supply of which was significantly lacking. Despite the difficulties caused by the lack of maps, Hungarian troops - as a result of their selflessness and high level of service - accomplished their mission efficiently and with minimal losses. Having taken into account the lessons learned from the 1968 invasion, the military mapping means of the Hungarian People's Army was reorganized.

\section{Key words:}

cartographic service in the Hungarian People's Army ； 1968 Invasion of Czechoslovakia ; "Zala" military exercise of the Hungarian People's Army ; cartographic provision of the "Zala" military exercise ; military geography of Highland of historical Hungary

\footnotetext{
* Open Researcher and Contributor ID = Nyílt Kutató és Közremüködő Azonosító (ORCID) https://orcid.org/0000-0002-2310-7746 Institutional attachements $=$ Szerző intézményi kötődései :

- Bertalan Szemere Scientific Society of History of Hungarian Law Enforcement = Szemere Bertalan Magyar Rendvédelem-történeti

- Museum of Military History

Tudományos Társaság

- Military History Review

= Hadtörténeti Intézet és Múzeum

Date of registry $=$ Regisztrálás dátuma : 2019. I. 20.

@: suba.janos@mail.militaria.hu

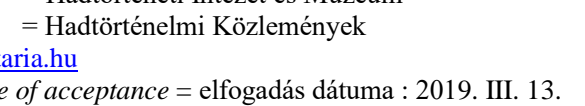

= Hadtörténelmi Közlemények

DOI : 10.31627/RTF.XXIX.2019.57N.59-68P 
A Csehszlovákiát megszálló intervenciós alakulatok térképellátását befolyásolta a magyar csapatoknak kiutalt müködési terület és a harci feladat. A tervek minden variációra elkészültek. A határőr alakulatok legfontosabb feladata volt a csehszlovák határ őrsök kikapcsolása (személyi állományuk lefegyverzése), a hadosztályok felvezetése a határátkelőhelyekre, a dunai hajóforgalom ideiglenes leállítása a határsávban. A lefegyverzett csehszlovák határőröknek 1968. VIII. 21-én este a magyar határörök már visszaadták a fegyvereiket, és együtt járöröztek.

A csehszlovák alakulatok parancsra nem tanúsítottak ellenállást, valamint első vonalbeli feltöltött csehszlovák alakulat nem volt a területen. A legfontosabb dolog a gyorsaság volt, ezért a hadtápot leválasztották a harcoló alakulatoktól, amelyek csak egy napi harctevékenységhez elegendő lőszert, élelmiszert, üzemanyagot és minimális egészségügyi anyagot vittek magukkal. A kora hajnali órákban a városokat blokkírozták, a csehszlovák alakulatokat lefegyverezték. A városok vezetőit összegyüjtötték, hogy megbeszéljék a további teendőket. Később az összeütközések elkerülése végett a fontosabb városokból kivonták a magyar alakulatokat, akik a közeli erdőkben táboroztak, de továbbra is fenntartották a városok blokádját. A hadosztály 10 helyőrséget hozott létre, majd a helyőrségekből kiindulva állandó járőrözéssel - a megszállás első és második napján - ellenőrzés alá vonták a vonzáskörzetükbe eső falvakat, településeket, szövetkezeteket, állami gazdaságokat. A magyar alakulatok október végéig katonai közigazgatási feladatokat láttak el.

\section{A terület katonaföldrajzi értékelése}

Minden háború konkrét térségben és konkrét időben, meghatározott és megkülönböztethető fizikai feltételek között folyik. Ha ezek a feltételek — amelyeket gyakran földrajzi tényezöknek neveznek nem is döntik el a háború sorsát, mégis lényegesen befolyásolják a mindenkori hadszíntérnek megfelelő harceljárás és harcvezetés kialakítását, a haderőnemek és fegyvernemek, a szakcsapatok és szolgálati ágak alkalmazását, szervezését és kiképzését.

A Kisalföld Dunától északra eső részének katonaföldrajzi értékelését - amit a magyar csapatok szálltak meg - egyrészt nem lehet elszakítani a Felvidék értékelésétől, másrészt a hadmüveleti területet ábrázoló térképektől.

A mai Szlovákia északi, északnyugati határa - a történelmi Magyarország határaként — a térség legállandóbb határa volt a történelem folyamán.

Szlovákia uralkodó felszíni formája a hegyvidék, ami az ország védelme szempontjából kedvező. A járható irányok lezárása egyben az ország védelmét is jelenti. A Duna dévényi áttörése és a Topla völgye között az Északnyugati-, és ettől keletre az Északkeleti-Kárpátok vonulatai húzódnak. A Kárpátok jelentős területei nehezen járhatók. Az észak-déli irányú völgyek kedvező védelmi lehetőségeket és ellátási feltételeket biztosítanak.

A határok zöme jól védhető, természetes határ. A határszakaszok a védelem szempontjából természetesen nem egyenértéküek. A magyar határszakasz 677,2 km-éböl 310 km - a közös határ 46\%a - természetes vonalon vezet. Ez a természetes védelmi vonal nyugati és keleti szakaszra osztható.

A nyugati szakaszt $142 \mathrm{~km}$ hosszan a Duna képezi (az 1850. és 1709. fkm között). A Duna méreteinél és jellemzőinél fogva nehezen leküzdhető 250-600, néhol 600 méter feletti szélességü hadmüveleti szintủ akadályt képez, amelynek leküzdéséhez jelentős nagyságrendủ átkelő eszköz szükséges.

A Duna szigetközi szakasza 1968-ban átkelésre kedvezőtlen. A sok ágra szakadó folyó és holtágai és a nagy vízsebesség jelentősen növelik az akadály jellegét.

Ezt tovább fokozza a fóágtól 7-10 km távolságra fekvő Mosoni-Duna ág is. A két ág között elhelyezkedő Szigetköz a számtalan egymásba fonódó csatornával, a morotva hálózattal, vizenyős rétekkel, kiterjedt ártéri erdeivel nehezen járható, vagy járhatatlan akadályt képez.

Ugyancsak természetes akadályt jelent még az Ipoly $110 \mathrm{~km}$, a Hernád $6 \mathrm{~km}$, a Ronyva $15 \mathrm{~km}$, és a Tisza $37 \mathrm{~km}$ hosszan. A határ mentén végig alföldi terület található.

Az észak-déli irányú folyóvölgyek kedvező védelmi lehetőséget nyújthatnak.

Szlovákia Pozsony és Kassa városok által uralt kétközpontú ország, melyet a megszállás szempontjából is figyelembe kellett venni.

Fővárosa, Pozsony közvetlenül az osztrák-magyar-csehszlovák határ mentén fekszik, ezért fokozottan veszélyeztetett helyzetü. A Duna völgy irányában végrehajtott támadás Pozsony környéki ipartelepek elvesztését is jelentené. Azonban ez a gazdaság teljesítőképességét nem veszélyeztetné alapjaiban. 
Pozsony és Kassa a határ közelében fekszik, ezért a védelem szempontjából kedvezőtlen helyzetben vannak.

Az ország kedvezőtlen alakja miatt egy észak-déli irányú harcászati méretü betörés már hadászati jelentőséggel bírhat.

A határtól számított 50 km-es sávon belül olyan nagyobb városok és járásközpontok találhatók, mint például Komárom, Párkány, Érsekújvár, Dunaszerdahely, Rimaszombat, Rozsnyó stb. Ezek elvesztése egyben a régió elvesztését is jelenti.

A Vág, Nyitra, Hernád és a Garam völgyében a járható irányok mentén városok alakultak ki. Ezért ezek a városok, - mivel járható irányokban fekszenek — az országba betört ellenség hadmüveleti vagy harcászati irányaiba esnek, és azok lehetséges célpontjai.

Földrajzi potenciálja miatt hosszú, elhúzódó konfliktusra nem alkalmas. Például domborzati viszonyai nem kedvezőek a mezőgazdaság számára, mert az alföldi területei a határ mentén 50 km-es sávon belül helyezkednek el. E területek elvesztése komoly ellátási zavarokat okozhat. Ezen kívül nyersanyagokból és energiahordozókból a régió jelentős behozatalra szorul.

Egy esetleges nagyméretü európai konfliktus esetén, a föirány határán fekszik.

A népesség jelentős része nem az államalkotó nemzethez tartozik.

Járhatalan, illetve igen nehezen járható szakaszok a Kárpátok középhegységi részein, továbbá a Vihorlát egyes tájain találhatók. Az észak-déli irányú folyók (Vág, Nyitra, Garam, Ipoly) akadály jellegét elsősorban az időszakonkénti nagy vízsebességük, meder- és partviszonyaik, változó vízállásuk, több hétig tartó tavaszi áradásuk (kivéve a Garamot, amely hirtelen árad, de gyorsan apad) jelenti.

Az alföldi területeken kedvezőek a mozgási lehetőségek, főként száraz időben. Esős időszakban — egyrészt a magas talajvízszint, másrészt a Duna magas vízállása miatt — romlanak a mozgás feltételei a folyók menti területeken. Ilyenkor csak a folyóktól távolabb fekvő részeken biztosított a megfelelő kelet-nyugat irányú mozgás.

Az álcázási feltételek e területen — a folyó mente kivételével — a mezőgazdasági müvelés intenzitása miatt kedvezőtlenek.

Szlovákia déli részén a kelet-nyugat irányú mozgást elsősorban nem a folyók akadály jellege befolyásolja — eltekintve az áradásos időszaktól — hanem a folyók egymástól való kis távolsága (VágNyitra 10-30 km, Nyitra-Garam 30-40 km, Garam-Ipoly 10-20 km). E terület északi részén a folyók közötti hegységi részek, illetve azok úton és úton kívüli járhatóságának igen korlátozott volta jelentősen nehezíti kelet-nyugati irányú mozgást.

Megemlíthető még a jelentős területen előforduló agyagos talajt, amely esős időben nehezen járható.

Közúti és vasúthálózata általában egymással párhuzamosan halad. Ezért hasonló mértékben léphetnek fel müködési zavarok mindkét szállítási ágban. A nagyszámú közúti- és vasúti híd, valamint az alagutak miatt könnyen zavarhatók a térségben a csapatmozgások. A védők szempontjából viszont kedvező lehetőséget biztosít a támadók megállítására. Az utak jellegzetesen észak-déli vonalvezetésúek, lényegesen kevesebb a kelet-nyugat irányú út, de ezek jellegük és az átmenő forgalom miatt nagyon fontosak.

A magyar határ közelében három, határhoz kifutó, jelentősebb út található. Az egyik Csallóköz területéröl Szigetközön át Győr irányában halad, a másik ettől keletre, 40 km távolságra Komáromnál, ahol közúti-, és vasúi híd is van. Az Ipoly torkolatától keletre fekvő területeken 14 út vezet, amelyek minősége közepes és gyenge. A határon átmenő útsűrüség $34 \mathrm{~km}$, ami közepes érték, bár minőségi szempontok sokat rontanak rajta. A határhoz közel, már 15-25 km-re és átlag 30-50 km-re jelentős útés völgycsomópontok találhatók, ott, ahol az utak összefutnak.

Szlovákiában, nyugat-keleti irányban egymással párhuzamosan négy fő haránt irányú közlekedési útvonal (északi, középső és déli, és a déli határ mentén) halad, így bármelyik kiesése esetén az átcsoportosítás után nem szakad meg az összeköttetés.

Vasúthálózata széleskörü kapcsolatot teremt az összes nagy és kistelepülés között. A néhai Csehszlovákia földrajzi fekvése indokolta, hogy egy olyan irányú fövonalat építsenek ki, amely összeköti a Cseh-medencét és Szlovákiát. Ez a Prága-Kolin-Olmütz-Ostrava-Zsolna-Poprad-Kassa-Tiszacsernyő fővonal volt.

A közlekedési viszonyok tehát — a földrajzi helyzetét figyelembe véve —összességében jónak mondhatók. 
Szlovákia déli irányból való megtámadásánál a Duna széles vízi akadályt jelent. Az esetleges támadó mélységben a zömmel észak-déli irányú folyóvölgyekre támaszkodó és fokozatosan kiszélesedő úthálózatot elörevonási, illetve után- és hátraszállítási vonalként használhatná fel. Egy sikeres Dunai átkelés és térnyerés estén a folyót haránt irányú összeköttetésre lehet felhasználni.

Szlovákia alföldi területe — kiterjedésénél fogva — több hadtest nagyságú erő befogadását és elhelyezését biztosítja a védekező számára. A Duna itteni szakasza a teljes hosszában széles akadályt képez.

A hadműveleti térségről — az ellenségnek és a valószínü tevékenységi körzetnek megfelelően katonaföldrajzi leírások készültek. Ezek a haderő és a fegyvernemek célszerű alkalmazására vonatkozó útmutatásokat tartalmazzák. A katonaföldrajzi leírásokat a parancsnokoknak a tervezett harcbavetésüknek megfelelően adták ki. Így a parancsnokok és a törzsek időben megismerkedhettek a valószínú tevékenységi körzet sajátosságaival. ${ }^{1}$

\section{A Magyar Néphadseregben rendszeresített térképek és azok biztosítását befolyásoló tényezők}

A térképészeti biztosítás azon intézkedések összegsége, amelyeket békében és háborúban a csapatok harctevékenységének előkészítésekor és annak folyamán végre kell hajtani. Vagyis ez a harctevékenység hadmüveleti és harcászati biztosításának szerves része. Feladata: a harcfeladat megoldásához az ellenségről és a terepről szükséges adatokat tartalmazó topográfiai és különleges térképek, geodéziai pontjegyzékek, valamint egyéb térképészeti rajzolt harci okmányok készítése és a csapatok ezekkel történő ellátása.

A Magyar Néphadseregnél a tárgyalt időszakban a térképészeti biztosítást a Vezérkar Hadműveleti Csoportfőnökségének térképész osztálya - fedőnevén az „F” osztály — (8 fö) irányította. ${ }^{2}$

A térképész osztály alárendeltségébe tartozott a Magyar Néphadsereg Térképészeti Intézete és a Magyar Néphadsereg Központi Térképraktára. Az osztály vezetője az Magyar Néphadsereg valamenynyi térképész beosztású katonájának, térképész szervének szakmai elöljárója volt.

A hadmüveleti csoportfönökségnek való alárendelésnek voltak hátrányai és előnyei. A hátrány az volt, hogy a térképész szolgálat irányításához a vezetési hierarchiában kijelölt hely kisebb jog- és hatáskört biztosított. (Szükség volt a polgári térképészettel való együttmüködésre, a szövetséges hadseregek térképész szolgálataival való dinamikus kapcsolattartásra, stb. A kapcsolatok szakmai jellegüek, de a szervezeti jellegből adódóan az ilyen kérdésekben is a hadmüveleti csoportfőnöknek kellett állást foglalni. Ezek az ő rendeltetésszerü feladataihoz képest periférikusak voltak, bár kétségtelen, hogy a térképészeti feladatok végrehajtásánál döntésének súlya és tekintélye előnyösen hatott.)

A nemzetközi indíttatású katonai térképészeti feladatok végrehajtásának előkészítését és irányítását befolyásolták a Magyar Néphadsereg intenzív fejlesztésével összefüggő feladatok, lehetőségek és gondok. Az osztály tevékenységében jelentős arányban szerepeltek szervezési feladatok, a szakkáderek utánpótlásával, képzésével, kiképzésével, beosztásba való helyezésével összefüggő tennivalók és problémák, és napirendre kerültek a haditechnikai fejlesztési problémák is. ${ }^{3}$

Csehszlovákia megszállásának időszakára értek be a Magyar Néphadsereg alakulatai térképészeti biztosítottsága előkészítő munkáinak gyümölcsei. Ennek részeként korszerüsítették a térképellátást és a tereptan oktatási színvonalát is emelték. Az 1960-as években végrehajtott parancsnoki, törzsvezetési és harcgyakorlatok során kiderült, hogy a törzsek és alegységek sok tisztjének tereptani felkészültsége nem kielégítő. (1956 óta nem volt gazdája a tereptan oktatásának és a kiképzésnek.) a térképész osztály kapta meg a tereptan kiképzés elvi irányítását. Ez az osztály 3-4 év alatt célirányos és aktív tevékenységgel jelentős változást és eredményt ért el a tisztek tereptani kiképzésében és továbbképzésében.

Az 1964. évi tereptani kiképzési értekezlet határozatainak megfelelően sikerült a tereptani kiképzés óraszámát a korábbi többszörösére emelték, a Magyar Néphadsereg Kiképzési Főcsoportfönökség illetékes szerveivel való együttmüködés kialakításának segítségével.

A kiképzési követelményeket és a programokat jobban a kiképzés céljához igazították.

A seregtest és magasabb egységek térképész szolgálati fönökei térképész tisztek mozgósítása útján törekedtek eredményt elérni a parancsnokságok tisztjeinek tereptani továbbképzésében. A Térképészeti Intézet tisztjeiből előadói csoportokat szerveztek, akik 1966-1967-ben több száz órában tartottak tereptani foglalkozásokat seregtest-, magasabbegység-, és egység-parancsnokságok hivatásos állománya számára. 
Ezzel párhuzamosan jelentek meg a tereptani tankönyvek és segédletek, valamint a különböző méretarányú topográfiai térképek jelkulcsai. ${ }^{4}$

A hadmüveleti követelmények változásával kapcsolatban a térképész szolgálat 1964-ben másodszor is végrehajtotta a csapatok mozgósítási (M) zárolt térképkészletekkel való ellátását. Ezzel elérte, hogy minden békében meglévő és minden $M$ esetén felállítandó katonai szervezet a háború kezdeti időszakában szükséges térképkészletekkel a helyszínen, zárolt készletek formájában rendelkezzen. ${ }^{5}$ Ezt követte a csapatok térképellátó szervezeti korszerüsítésének előkészítése és végrehajtása, a számítógépes térképnyilvántartás bevezetése. 1965-ben térképellátási utasítás jelent meg. ${ }^{6}$

A katonai térképészet a vizsgált időszakot a Varsói Szerződés feladatai térképészeti biztosításának a kidolgozása és végrehajtása jellemezte. A katonai térképész szolgálatok vezetői 1966-ban, Moszkvában tanácskoztak az aktuális feladatokról. Többek között a Varsói Szerződés tagállamaiban kiadásra kerülö topográfiai és különleges térképek tartalmi egységének biztosításával kapcsolatos témákról tárgyaltak.

Ebben az időszakban a Varsói Szerződés tagállamai haderőinek térképész szolgálatai között kezdtek kiszélesedni - mindenekelőtt tapasztalatszerzés céljából — a kétoldalú kapcsolatok is. 1967 decemberében a Csehszlovák Néphadsereg térképész szolgálatának főnöke tárgyalt Budapesten.

Az 1: 25000 méretarányú térkép a helyszíni felmérés teljes tartalmú másolata, minden más katonai térkép alapanyaga. ${ }^{7}$ Mint a magyar haderő legnagyobb méretarányú térképe a honvédség fő harcászati térképe volt. Az összfegyvernemi egységek (alegységek), különösen a vízi akadályok leküzdésénél, nagyobb városokért folytatott harctevékenységnél és a megerődített körletek elleni harc során használhatták.

Az 1: 50000 méretarányú térkép — mint harcászati térkép — az alsóvezetés térképe volt. ${ }^{8}$ A csapatok számára szükséges adatokat kellő részletességgel ábrázolta, elég nagy területen. Különböző mérések és számvetések elvégzésére volt alkalmas. A szakasz- és század-parancsnokok térképe volt.

Az 1: 100000 méretarányú térkép az általános és a gyors tájékozódás eszköze volt. ${ }^{9}$ Mint alapvető hadmüveleti és harcászati térkép, a terep tanulmányozásának és a harc megtervezésénak, megszervezésének, valamint a müszaki rendszabályok tervezésének, továbbá a szervezéseknél az előzetes számvetés elkészítésének a hathatós segédeszköze volt. Ha nagyobb méretarányú térkép nem állt rendelkezésre, a tüzérségi tüz előkészítésére is felhasználható volt. E méretarányú térképpel kellett ellátni minden tisztet, századparancsnokig bezárólag.

Az 1: 200000 méretarányú térkép a katonailag fontos helyszínrajzi adatokat összefoglalva ábrázolta. ${ }^{10} \mathrm{~A}$ várható harctevékenység sávjában a terep általános tanulmányozására, értékelésére, a hadművelet tervezésére és szervezésére, a csapatok vezetésére és a csapatmozgások megvalósítására használhatták. A gépkocsizó lövész és harckocsizó magasabbegységek elsősorban az ellenség üldözésénél alkalmazhatták. E méretarányú térképekkel kellett ellátni a földi és rakéta-, valamint a légvédelmi csapatokat, zászlóaljig (osztály) bezárólag. Közlekedési és katonaföldrajzi célokra ez a térkép volt a legmegfelelőbb, amely a katonai középvezetés térképének bizonyult. A repülőcsapatoknál tájékozódásra, felderítő repülőknél az ellenséges objektumok koordinátáinak meghatározására is használható volt.

Az 1: $500000^{11}$ és az 1: $1000000^{12}$ méretarányú térkép a Magyar Néphadsereg hadmüveletiharcászati térképe volt. Elsősorban a vezérkar, a frontok és hadseregek törzseinek hadműveleti munkáihoz, a tervezéshez és a csapatok harctevékenységének biztosítására vonatkozó intézkedések kidolgozásához használhatták. Ezen kívül pedig a repülőcsapatok fö térképeként is szolgált.

A várostérképek az egyes nagyobb és fontosabb településekről általában 1: 10000 és 1: 25000 méretarányban készültek. A harctevékenység tervezésekor és szervezésekor az objektumok részletes tanulmányozására, a csapatok vezetésére, tájékozódásra és célfelderítésre voltak használhatók. Ezeket a térképeket, mint térképészeti alapot, rajzolt harci okmányok elkészítésénél is fel lehetett használni.

A geodéziai pontok koordinátáinak katalógusa, ${ }^{13}$ a tüzérpontjegyzék, arra szolgált, hogy biztosítsa a tüzérség számára a geodéziai kezelőadatokat, melyek a tüzérségi alappont hálózat kifejlesztéséhez, valamint a tüzérségi figyelőállások és figyelőpontok közvetlen bekötéséhez lehettek szükségesek. Ezek 1: 50 000, 1: 100000 vagy 1: 200000 méretarányú térképszelvényenként kerültek kiadásra. Ezekkel a tüzér-, légvédelmi tüzér-, és a különleges repülő egységeket látták el.

Ezen kívül a Magyar Néphadsereg különleges térképekkel is rendelkezett, amelyekkel azonban csupán speciális esetekben látták el a különleges alakulatokat. 
Szlovákia — viszonylag kis területü, — mindössze $49000 \mathrm{~km}^{2}$ kiterjedésü ország. Ezért kevés térképszelvény fedi le. Az 1: 100000 méretarányú térképekből 54 db, a kétszázezres méretarányúakból $20 \mathrm{db}$, a félmilliós méretarányúakból 4 ( 1 teljes és 3 csonka) szelvény fedi le a szlovák területet.

Csehszlovákia térképműveinek jellemzői - vetület, méretarány, tartalom, stb. szempontjábólmegegyeztek a magyar térképmüvek paramétereivel, hiszen, mint koalíciós partnerre, a Varsói Szerződésben ugyanazok az előírások vonatkoztak a csehszlovák térképekre és térképészeti előírásokra is.

A Varsói Szerződés tagállama lévén - a koalíciós elöírásoknak megfelelően — Csehszlovákia területéről nem álltak rendelkezésre kis méretarányú térképek.

A 677 km közös határszakasznak köszönhetően elsősorban a határmenti területekről voltak térképek. A határmenti szelvények teljesek voltak minden méretarányban.

Csehszlovákia területéről csak 1: 200000 méretarányban álltak rendelkezésre térképek. Az 1: 200 000 és az 1: 500000 méretarányú térképek szovjet alapanyagokból készültek, a névrajz egy részének magyarosításával. ${ }^{14}$

A térképek alapvetően - a koalíciós együttmüködésből fakadó feladatok miatt — hadsereg- és front-parancsnokságok, valamint törzsek számára készültek.

A térképek 1: 200000 és a határmenti területeken 1: 100000 méretarányúak voltak.

Az 1: 200000 méretarányú Pozsonyt (M-33-XXXVI.) ábrázoló térképszelvény tervezése 1967ben kezdődött el, az 1966-os kiadású százezres térkép alapján. A határon túli részt az 1963. évi kiadású 1: 200000 méretarányú szovjet térkép alapján készítették, és 1968-ban sokszorosították, majd 1976-ban aktualizálással egybekötve újranyomtatták.

E térképszelvény elődje is megtalálható volt a raktári készletben. Ez a térkép az 1962-es kiadású csehszlovák térkép magyar szövegü másolata volt, amelyet 1963-ban adtak ki. Ez azt jelentette, hogy a névrajz egyes rövidítéseit az egyes jelkulcsi elemeknél, elsősorban a mezőgazdasági objektumoknál (állami gazdaság, major) magyarul írták ki, illetve rövidítették.

A Pozsony melletti Nyitra (M-34-XXXI.), és a Salgótarján (M-34-XXXII.) szelvények az 1: 200 000 méretarányú, 1955-ös kiadású csehszlovák térkép 1963. évi helyesbítése és 1964. évi kiadása voltak.

Az ettől a sávtól északra lévő területet ábrázoló Zlín (1949-1989 Gottwaldov) (M-33-XXX.) az 1962. évi szovjet 1: 200000 méretarányú szelvény 1963. évi helyesbítése és 1964. évi kiadása volt. A Zsolnai (M-34-XXV.) szelvény szovjet alapanyagát 1965-ben helyesbítették és 1966-ban adták ki elöször. A csatlakozó szelvények helyesbítési és kiadási évei egy-két év eltérést mutatnak.

$\mathrm{Az}$ 1: 200000 méretarányú térképszelvényeken a térkép mellett a terep katonaföldrajzi leírása (a terep általános jellemzése: települések, úthálózat, domborzat és talaj, vízrajz, növényzet leírása és az időjárási viszonyok jellemzése) található.

Az 1:100 000 méretarányú térképek szintén a határmenti területről készültekk. Alapanyagukat a rendelkezésünkre álló 1959-1961. évi kiadású csehszlovák térképek alkották. Például a Pozsony (M33-143.) 1966, Galánta (M-33-144.) 1968, a Nyitrai (M-34-133.) szelvény 1968. évi kiadású volt.

\section{Csehszlovákia megszállásában résztvevő magyar csapatok térképellátásának biztosítása}

A magyar eröknek kiutalt $10000 \mathrm{~km}^{2}$-es terület 1968. VIII. 25-töl $1500 \mathrm{~km}^{2}$-rel, azaz Nagyszombat körzetével nőtt. A 8. gépkocsizó lövész hadosztály körletét $9 \mathrm{db}$ 1: 100000 (ebböl 4 határmenti szelvény), 3 darab (2 egész és 1 csonka) 1: 200000 méretarányú szelvény fedte le. ${ }^{15}$

A magyar kontingens térképészeti biztosítását, a Magyar Néphadsereg harctevékenysége térképészeti biztosítására vonatkozó szabályzatban foglaltaknak megfelelően valósították meg. ${ }^{16}$

A 8. gépkocsizó lövész hadosztályt a vezérkar térképész szolgálata látta el térképekkel. A térképész szolgálat fönökségnek volt a feladata, hogy kellő időben térképkészletet képezzen a várható hadmüvelet teljes mélységére, továbbá idejében egészítse ki a térképkészletet a csapatok harctevékenysége irányának megváltozása esetén.

A 8. gépkocsizó lövész hadosztály a térképellátási normák szerint kapta meg a térképeket és a geodéziai pontjegyzékeket. 1968. VIII. 19-én a 95. gépkocsi szállító zászlóalj szállította ki a térképek mozgó készletét a 8. gépkocsizó lövész hadosztályhoz. ${ }^{17}$

A „Zala” feladattal kapcsolatos térképbiztosítási teendőket a Magyar Néphadsereg illetékes szervezetei a Honvédelmi Minisztérium operatív biztosítócsoportja által megszabott határidőre végrehajtották. A térképészeti biztosítást elsősorban a térképellátási teendők végrehajtása jelentette. ${ }^{18}$ 
A kijelölt csapatokat és törzseket honi területre az általuk igényelt méretarányú és mennyiségü térképpel látták el.

A honi területen kívüli feladatok végrehajtásához viszont csak 1: 200000 méretarányú térképeket tudtak biztosítani. Ezzel kapcsolatban több észrevétel hangzott el a csapatok részéröl.

A 8. gépkocsizó lövészhadosztály azt jelentette, hogy „. . . a harcfeladat megkezdése és végrehajtása során rendkivül kínosan éreztette hatását a szükséges méretarányú (elsösorban nagy, 5-1025-50 00-es) térképek hiánya, mindenekelött a felderitők, a tüzérség, valamint egyes objektumok (pl.: városok) birtokbavételét tervezö összfegyvernemi törzsek munkája szempontjából. Ez az igény annál is inkább elötérbe került, mert a feladat végrehajtásához, illetve a kijelölt objektumok gyors elfoglalásához szükséges megfelelö helyismerettel rendelkezö személyek sem álltak rendelkezésünkre."19

A hadosztály rakéta-tüzérfőnöke azt jelentette, hogy „. . . gátolta a részletek kidolgozását, hogy kis méretarányú térkép állt rendelkezésre. Az 1: 200000 méretarányú térképek 6-7 évvel korábban lettek felvéve, $s$ azok is csak igen kis mértékben álltak rendelkezésre". ${ }^{20}$

A hadosztály felderítőfönök azt jelentette, hogy „Jelentős befolyással volt az is, hogy a felderitöszervek nem voltak ellátva megfelelö térképekkel." 21

A rendelkezésre álló kisméretarányú térképek pontatlanok voltak. A feladat elökészítése és végrehajtása folyamán térképellátási problémák is felvetődtek. Ez gátolta a felderítő szervek eredményes, gyors, pontos tevékenységét. Ezt erősítik meg a többi ezred- és osztály-parancsnok jelentései is.

A 1: 200000 méretarányú térképek nem biztosítottak megfelelő alapot a kellő tájékozódáshoz, méretarányuknál fogva nem voltak alkalmasak a helységek tanulmányozására és az azokban való tájékozódásra. Az ilyen méretarányú térkép a menet megszervezéséhez és végrehajtáshoz megfelelő volt ugyan, azonban a kisebb alegységek harcfeladatainak megszervezésére már alkalmatlannak bizonyult.

A térképészeti osztály később javasolta, hogy a „Rába” feladat keretében vizsgálják meg nagy méretarányú térképek készítésének szükségességét a szocialista országok területére.

A honi területen kívüli feladatok térképészeti biztosítása során beigazolódott, hogy a magasabb harckészültségi fokozat elrendelése után a jelenlegi térképellátó szervezet (ezredenként egy-egy megbízott térképkezelő tiszt) nem tudja ellátni — egyéb szolgálati beosztással járó feladatai miatt — a csapatok és törzsek térképellátását.

A 63. gépkocsizó lövészezred parancsnoka azt jelentette, hogy „Az egész feladat során állandó térképellátási problémákkal küszködtünk. " A 95. gépkocsi szállító zászlóalj is kevés térképpel rendelkezett, összesen három készlet volt biztosítva a számukra. Viszont a 42. felderítő zászlóaljnál a térképellátás folyamatos volt. ${ }^{22}$

A felmerülő nehézségeken megkíséreltek úrrá lenni.. A 6. gépkocsizó lövész ezred jelentette, hogy több esetben nagyításokat kellett végrehajtani az 1: 200000 térképekről. Mivel ez a térkép nem volt elég részletes, a tereppel egyeztetni kellett és a hiányzó adatokat fel kellett szerkeszteni a térképre, amely igen sok időt vett igénybe. ${ }^{23} \mathrm{~A}$ későbbiek folyamán az ezred 1: 50000 méretarányú térképeket és légfotókat is kapott.

A 93. páncéltörő tüzérosztály jelentette, hogy az osztálytörzs a rendelkezésére bocsátott pontjegyzék 1: 100000 méretarányú térképéről 1: 50000 méretarányú oleáta-vázlatot készített birtokba veendő területekröl. ${ }^{24}$

A A8. gépkocsizó lövész hadosztály parancsnoka 1968. VIII. 25-én arra kérte az Országos Légvédelmi Parancsnokságot (OLP), hogy a magyarok által megszállt területröl légifilm sorozatot készítsenek. Az OLP intézkedésére felszállt repülőgépeket a hadsereg parancsnokság utasítására visszafordították a határról. 1968. VIII. 26-án ismét előkészítettek repülőgépeket légifényképezésre. Végül is 1968. VIII. 27-én került sor a légifényképezésre. A légi fényképezést a Térképészeti Intézet béke szervezetében müködő repülő személyzetével és eszközeivel valósították meg.

A légifényképeket kiértékelték és kirajzolták rajta a táborhelyeket, laktanyákat — gyakorlóterekkel együtt -, a raktárakat, a repülőtereket, a vízmüveket és az egyéb fontos objektumokat. A kiértékelt légfotókat a csapatok rendelkezésére bocsátották.

Ezzel kapcsolatban merült fel, hogy a Térképészeti Intézet hátországi szervezet, ezért a mozgósítás után a légifényképezés és kiértékelés elvégzésére nem lehetett volna lehetősége, mert a háborús szervezetre való áttérés esetén a légifényképezéssel kapcsolatos feladatok végrehajtására csak az OLPnek volt hatásköre. Ezért a térképészeti osztály vezetője a téma komplex felülvizsgálatát és az OLPvel való együttmüködés újra szabályozását javasolta. ${ }^{25}$ 
A térképellátás problémái befolyásolták a felderítés és a müszaki biztosítás hatékonyságát is. A Magyar Néphadsereg müszaki főnöke megállapította, hogy szükségesnek látszik a jövőben a várható alkalmazási vagy elörevonási irány katonaföldrajzának részletes tanulmányozása, feldolgozása, a meglévő térképeink folyamatos pontosítása. ${ }^{26} \mathrm{Ez}$ a „Börzsöny” tervben megvalósult.

Összességében megállapitható, hogy a „Zala-gyakorlat” végrehajtása térképészeti biztositásának a nehézségei pozitiv hatást gyakoroltak a Magyar Néphadsereg térképellátási rendszerének a fejlesztésére. 1968-ban kidolgozták az elgondolást a csapatok térképellátó szervezetének korszerüsítésére, amelynek alapján 1970. III. 1-jei hatállyal az egységeknél a térképellátás — hozzá a személyi feltételeket is biztosítva - a titkos iratok ügyviteli irodáinak a feladatkörébe került.

1968-ban a térképészeti osztálynak sikerült elérnie, hogy az 5. hadsereg és a 3. hadtest térképész szervezet „Térképész Szolgálat” megnevezést kapjon. Ez az előrelépés az OLP-nél és az alárendelt magasabb egységeinél, valamint a szárazföldi csapatok magasabb egységeinél 1969-ben valósult meg.

1968-ban került sor az eddig mozgósítási alakulatként funkcionáló 17. önálló térképező zászlóalj hivatásos állományának tartalékosokkal kiegészített gyakorlatára. E mozgósítási-összekovácsolási gyakorlat, és a júniusban, a Német Demokratikus Köztársaságban tett tanulmányút tapasztalatit vették figyelembe a szervezeti keretek kialakításánál, amikor csökkentett békeállománnyal megalakult 1969 őszén az 5. hadsereg-parancsnokság alárendeltségében a 17. önálló térképező zászlóalj.

Álláspontom szerint a csehszlovákiai magyar intervenció összességében egy jól szervezett - a hibákkal együtt — katonailag magas szinten megoldott hadmüvelet volt, amely könnyen véresen komollyá válhatott volna. Azonban nem így történt, amely nagyrészt a katonáknak volt köszönhető, akik erejük és tudásuk legjavát adták. Történelmi tény ugyan, hogy a Magyar Néphadsereg térképellátó rendszere ekkor még nem állt a helyzet magaslatán, azonban az is cáfolhatatlan tény, hogy a keletkezett tapasztalatok nyomán fejlesztették ki a Magyar Néphadsereg térképészeti szolgálatát. 
Jegyzetek:

${ }^{1}$ Szlovákia katonaföldrajzi képének megrajzolásához, nagyon sok mủ áll rendelkezésre, mind katonai, mind földrajzi.

Somogyi ; SzÁntó ; Kozma — HéJJA — Stefasncsik ; Siposné — SzTernák ; Térképszelvények M-33-XXXVI. , M-34-XXXI. , M-34-XXXII. , M-33-XXX. , M-34-XXV.

${ }^{2}$ HIM-HL. Pers. 241, Tanulmánygyüjtemény II. 1945-1991. 13,40.ifm. GADOs László: A Magyar Néphadsereg vezérkara térképész szervének története (1947-1980).

${ }^{3}$ GADOS: A haditevékenységek térképészeti biztosításának nehéz feladata. ; EGRESSY

${ }^{4}$ Katonai tereptan tankönyv. I-III.köt. ; Katonai tereptan példatár.

${ }^{5}$ 04193/1964. MNVK. 1.Csf-ség. Utasitása a térképraktárak müködésére.

${ }^{6}$ Utasitás a Magyar Néphadsereg alakulatai és katonai tanintézetei térképellátására. 31.p.

${ }^{7}$ HIM-HL. HT. B.XV.40.

${ }^{8}$ Loc.cit. B.XV.41.

${ }^{9}$ Loc.cit. B.XV.42.

${ }^{10}$ Loc.cit. B.XV.43.

${ }^{11}$ Loc.cit. B.II.51.

${ }^{12}$ Loc.cit. B.I.46.

${ }^{13}$ Loc.cit. IV.293.

${ }^{14}$ Loc.cit. B XV a 43.

${ }^{15}$ Északon Nagykürtös - Privigye - Vágújhely. Nyugaton a Vág folyótól keletre Vágújhely - Pöstyény - Nagyszombat Bélaháza - Szered. Délröl Érsekújvár - Duna - Párkány települések által közrefogott terület alkotta a Magyar Néphadsereg 8. gépkocsizó lövészhadosztályának a körletét.

PATAKY

${ }^{16}$ Utasitás a csapatok harctevékenységének térképészeti biztositására.

${ }^{17}$ HIM-HL. op.cit. 5/12-11. csomag. A 8. gk. lho. összefoglaló jelentése.

${ }^{18}$ SZÉKELY Tibor ezds. a térképészeti osztály vezetője foglalta össze a térképészeti biztosítás tapasztalatait.

HIM-HL. op.cit. 5/12-8. csomag. A „Zala” feladat térképészeti biztosításának tapasztalatai.

${ }^{19}$ HIM-HL. op.cit. 5/12-11. csomag. A 8. gk. lho. összefoglaló jelentése.

${ }^{20}$ HIM-HL. op.cit. 5/12-9. csomag. A 8. gk. lho. rakéta-tüzérfönökének összefoglaló jelentése.

${ }^{21}$ HIM-HL. op.cit. 5/12-11. csomag. A 42. felderítő zlj. harcállaspont pk. jelentése.

${ }^{22}$ Loc.cit.

${ }^{23}$ HIM-HL. op.cit. 5/12-11. csomag A 93. páncéltörö tüzérosztály jelentése.

${ }^{24}$ PATAKY: op.cit. 112.p. ; HIM-HL. op.cit. 5/12-19. csomag MNVK Hadmüveleti Napló I.

${ }^{25}$ HIM-HL. op.cit. 5/12-8. csomag. A „Zala” feladat térképészeti biztosításának tapasztalatai.

\section{Forrás- és irodalomjegyzék (a jegyzetekben alkalmazott röviditések oldása):}

\section{MONOGRÁFIÁK KISMONOGRÁFIÁK ÉS HASONLÓ JELLEGÜ KÖTETEK}

\section{PATAKY}

(15.;24.;)

SOMOGYI

(1.;)

SzÁNTÓ

(1.;)

\section{KÉZIKÖNYVEK}

KOZMA - HÉJJA - STEFASNCSIK

(1.;)

\section{TANKÖNYVEK}

Katonai tereptan tankönyv. I-III.köt. (4.;)

Katonai tereptan példatár.

(4.;)

\section{FELSŐOKTATÁSI JEGYZETEK}

SIPOSNÉ - SZTERNÁK

(1.;)
PATAKY Iván: A vonakodó szövetséges. Budapest, 1996, Zrínyi Katonai Kiadó. 171 p. HU-ISBN 9633272920.

- Somogyi Endre: Magyarország és a környék államainak katonai földrajza. Budapest, 1928, Somogyi Endre. 434 p.

- SZÁNTó Imre: Az európai hadszínterek katonaföldrajza. Budapest, 1964, Zrínyi Kiadó. 381 p. /Tisztek könyvtára, 18./

- KozMa Endre - HÉJJA István - STEFASNCSIK Ferenc: Katonaföldrajzi kézikönyv. Budapest, 1993, Zrínyi Kiadó. 175 p. HU-ISBN 9633272084.

- Katonai tereptan tankönyv. Honvédelmi Minisztérium.

- I.köt. Budapest, 1966, 279 p. (A kiadvány szabályzat besorolása Ált/16.)

- II.köt. Budapest, 1966, 144 p. (A kiadvány szabályzat besorolása Ált/17.)

- III.köt. Budapest, 1967, 234 p. A kiadvány szabályzat besorolása Ált/33.)

- Katonai tereptan példatár. Budapest, 1967, Honvédelmi Minisztérium. 268 p.(A kiadvány szabályzat besorolása Ált/32.).

- SIPOSNÉ Kecskeméthy Klára - SzTERNÁK György: Szlovákia katonaföldrajzi értékelése. Budapest, 1994, Zrínyi Miklós Katonai Akadémia. 93 p. (Jegyzet) 


\section{TANULMÁNYOK}

GADOS: A haditevékenységek térképé- szeti biztosításának nehéz feladata.

(3.;)

\section{SZABÁLYZATOK}

Utasitás a csapatok harctevékenységének térképészeti biztositására.

(16.;)

04193/1964. MNVK. 1.Csf-ség. Utasitása a térképraktárak müködésére.

(5.;)

Utasitás a Magyar Néphadsereg alakulatai és katonai tanintézetei térképellátására.

(6.;)

\section{TÉRKÉPEK}

M-33-XXXVI.

(1.;)

M-34-XXXI.

(1.;)

M-34-XXXII.

(1.;)

M-33-XXX.

(1.;)

M-34-XXV.

(1.;)

\section{KÉZIRATOK}

EGRESSY

(3.;)
GADOS László: A haditevékenységek térképészeti biztosításának nehéz feladata. Honvédelem, VIII.évf. (1964) 12.sz. 42-46.p.

Utasitás a csapatok harctevékenységének térképészeti biztositására. Budapest, 1962, Honvédelmi Minisztérium. 83 p. (A kiadvány szabályzat besorolása Ált./84.)

04193/1964. MNVK. 1.Csf-ség. Utasitása a térképraktárak müködésére. Budapest, 1964, Honvédelmi Minisztérium. 21 p.

Utasitás a Magyar Néphadsereg alakulatai és katonai tanintézetei térképellátására. Budapest, 1965, Honvédelmi Minisztérium. 31 p. (A kiadvány szabályzat besorolása Ált./68.)

— M-33-XXXVI. (Pozsony) $1: 200000$ méretarány

— M-34-XXXI. (Nyitra) $1: 200000$ méretarány

— M-34-XXXII. (Salgótarján) 1: 200000 méretarány

— M-33-XXX. (Gottwaldov) $1: 200000$ méretarány

— M-34-XXV. (Zlina) 1: 200000 méretarányú szelvény

- EGRESSY Zoltán: A fototopográfiai alegység térképész-harcászati tevékenysége és jövőbeli feladatai. Magyar Honvédség Térképészeti Intézet Könyvtára. (A kézirat másolata a szerző magángyüjteményében.)

\section{LEVÉL-, IRAT- ÉS DOKUMENTUMTÁRAK}

HIM-HL

(17.;18.;19.;20.;21.;22.,23.;24.;25.; 26.;)

HIM-HL. HT.

(7.;8.;9.;10.;11.;12.;13.;14.;)

HIM-HL. Pers.

(2.;)
HIM (Hadtörténeti Intézet és Múzeum) HL (Hadtörténelmi Levéltár)

(A térképészeti biztosítással kapcsolatos iratokat a Hadtörténeti Intézet és Múzeum Hadtörténeti Levéltára külön 68 doboznyi egységként őrzi „Zala gyakorlat” elnevezéssel, mely iratanyag rendezésére még nem került sor.)

- HIM (Hadtörténeti Intézet és Múzeum) HL (Hadtörténelmi Levéltár) HT (Hadtörténeti Térképtár)

- HIM (Hadtörténeti Intézet és Múzeum) HL (Hadtörténelmi Levéltár) Pers. (Personáliák) 